\title{
SARMATIAN GRAVES WITH HIDING-HOLES IN THE BOTTOM OF PITS IN KURGAN CEMETERIES OF THE LOWER VOLGA REGION ${ }^{1}$
}

\author{
Boris A. Raev \\ Federal Research Centre The Southern Scientific Centre of the Russian Academy of Sciences, \\ Rostov-on-Don, Russian Federation
}

\begin{abstract}
Introduction. The article discusses one of the types of hiding-holes that were made in Sarmatian graves of the Lower Volga region. Hiding-holes as a substantial element of a graves structure are typical for Sarmatian burials of the last century BC and the first centuries AD. They were built in the burial pit, as well as near it, as a rule, in the west soil. In the burial pit, these were usually made as niches in the bottom parts of the walls, though hiding-holes in the bottom of the graves are characteristic only for the Lower Volga region. Methods and materials. There are not very many graves with hiding-holes in the Volga Region - eight in total, and none of them have been found in the neighboring regions, or only single cases are known. Archive data on excavations of the kurgans in the region allows the author to specify some essential construction details of the graves with hidingholes. These holes were dug out in the bottom of the grave pits; they are round in shape, $0.3-0.5 \mathrm{~m}$ in diameter and $0.3-0.6 \mathrm{~m}$ in depth. A deceased was placed over the holes. A principal item always placed in all hiding-holes is a bronze cauldron, which in some cases is accompanied by other types of metal and ceramic vessels. The author comprehensively applies several scholarly methods of archaeological research. The first stage of collecting and initial processing of material included methods of external and internal analysis of sources taking into account professional characteristics of researchers. The primary classification method based on the similarity of objects, as well as the traditional method of comparative typology, was used at the interpretation stage. The interpretation of materials also required the use of the classical method of extensive parallels including ethnological examples. Results. Among the burials with hiding-holes in the bottom of the pits, the majority were burials of women. Considering not only the ordinary but also the sacred meaning that was attached to the cauldrons by the nomads of Eurasia, the author concludes that the hiding-holes in the bottom of Sarmatian graves blocked out by the body of the deceased, served not only as a secret place for treasures but had some others cult significance.
\end{abstract}

Key words: Early Iron Age, Lower Volga, Sarmatians, burial structures, hiding-holes, bronze cauldrons.

Citation. Raev B.A. Sarmatian Graves with Hiding-Holes in the Bottom of Pits in Kurgan Cemeteries of the Lower Volga Region. Vestnik Volgogradskogo gosudarstvennogo universiteta. Seriya 4. Istoriya. Regionovedenie. Mezhdunarodnye otnosheniya [Science Journal of Volgograd State University. History. Area Studies. International Relations], 2020, vol. 25, no. 4, pp. 200-213. (in Russian). DOI: https://doi.org/10.15688/jvolsu4.2020.4.13

\section{САРМАТСКИЕ ПОГРЕБЕНИЯ С ТАЙНИКАМИ В ДНЕ ЯМЫ В МОГИЛЬНИКАХ НИЖНЕГО ПОВОЛЖЬЯ ${ }^{1}$}

\author{
Борис Аронович Раев \\ Федеральный исследовательский центр Южный научный центр РАН, \\ г. Ростов-на-Дону, Российская Федерация \\ Аннотация. Введение. Статья посвящена одному из типов тайников, которые устраивались в погребениях \\ сарматского времени в Нижнем Поволжье. Тайники, как элемент обустройства погребального сооружения, \\ характерны для сарматских захоронений двух последних веков до н.э. и первых веков н.э. Они устраивались как
}


в самой могильной яме, так и рядом с ней, как правило, на выкиде. В яме это обычно ниши в придонной части стен, а тайники в дне могилы характерны только для территории Нижнего Поволжья. Методы и материальы. В Поволжье тайников не так много - всего восемь, в соседних регионах их либо нет, либо встречаются единичные случаи. Архивные данные позволили уточнить существенные детали конструкции могильных ям с тайниками. Последние представляют собой выкопанные в дне могильной ямы круглые в плане углубления диаметром от 0,3 до 0,5 м и глубиной $0,3-0,6$ м, перекрытые телом погребенного. Обязательным предметом, помещавшимся во все тайники, является бронзовый котел, с которым в некоторых случаях соседствуют другие металлические и керамические сосуды. В статье использованы несколько методов научного археологического исследования. На стадии сбора и первичной обработки материала - метод внешней и внутренней критики источников, учитывающий личностные характеристики ученых. Метод первичной классификации на основе сходства объектов и традиционный метод сравнительной типологии использовались на этапе интерпретации. Интерпретация потребовала также применения классического метода широких аналогий с привлечением этнографических параллелей. Результаты. Из исследованных захоронений с тайниками в дне ям большинство составляли погребения женщин. С учетом не только бытового, но и сакрального значения, которое придавалось котлам номадами Евразии, сделан вывод о том, что тайники в дне ямы, перекрытые телом умершего, служили не столько местом схрона сокровищ, сколько имели какое-то иное культовое значение.

Ключевые слова: ранний железный век, Нижняя Волга, сарматы, погребальные сооружения, тайники, бронзовые котлы.

Цитирование. Раев Б. А. Сарматские погребения с тайниками в дне ямы в могильниках Нижнего Поволжья // Вестник Волгоградского государственного университета. Серия 4, История. Регионоведение. Международные отношения. - 2020. - Т. 25, № 4. - C. 200-213. - DOI: https://doi.org/10.15688/jvolsu4.2020.4.13

Введение. В 1954 г. в кург. 55 Калиновского курганного могильника при раскопках В.П. Шилова было обнаружено сарматское погребение, в устройстве ямы которого фиксировалась необычная деталь. В центре ямы в дне была устроена яма-тайник округлой формы диаметром 0,95-0,75 м и глубиной 0,5 м. В ее дне было сделано конические углубление для ножки литого бронзового котла. Кроме него в тайнике находились еще несколько импортных металлических сосудов. Тело погребенной лежало в деревянной раме, перекрывавшей большую часть тайника, ближе к ее западной стенке (рис. 4,1$)[25$, с. $17-$ 18, табл. XXIV, 2; 26, л. 29].

Тайники в сарматских погребениях, в том числе на территории Нижнего Поволжья, не рассматривались в работах археологов как специфический элемент конструкции могильной ямы. Впервые краткое описание известных к тому времени погребений с тайниками привел В.П. Шилов $[29, \text { с. } 185-188]^{2}$, часть из них перечислена в работе А.С. Скрипкина [20, с. 186-187]. Априори считалось, что сделаны они в погребениях «знати» и предназначались для сокрытия от грабителей особо привлекательного инвентаря - изделий из драгоценных металлов [20, с. $187 ; 29$, с. 185, 188]. Все ниши-тайники, за двумя исключениями, ограблены, но там, где они уцелели, находи- лись элементы конской узды. В одном случае (Жутовский могильник, кург. 28/1) узда была украшена золотыми фаларами [10, с. 64-65, 86 , кат. № 48, 49; 28, с. 61] в другом (Октябрьский $\mathrm{V}$, кург. 1/1) - в нишу был положен набор железных инструментов и три (четыре?) пары удил с псалиями, плакированными золотыми полосками [12, с. $152-153$, рис. 4,5$]$. В сравнении с остальным инвентарем, даже в том случае, когда от грабителей уцелела только его часть, положенные в ниши-тайники предметы выделяются не столько своим богатством, сколько принадлежностью к значимой для кочевника вещи - конской сбруе.

Материалы и методы. Исследованный В.П. Шиловым в 1954 г. тайник относится к совершенно иному типу: он выкопан в дне могильной ямы, а после помещения в него части погребального инвентаря перекрыт телом покойного. Сейчас на территории Нижнего Поволжья известно восемь таких могил, специально они не изучались (рис. 2-5). В статье 1998 г. И.В. Сергацков перечислил известные к тому времени четыре нижневолжских погребения и одно погребение в бассейне Северского Донца [14, с. 154]. Одно из них включено А.С. Скрипкиным в перечень могил с тайниками, сосредоточенными, по мнению автора, на ограниченной территории левобережья Дона от реки Сал до Есауловского Ак- 


\section{АРХЕОЛОГИЯ РАННЕГО ЖЕЛЕЗНОГО ВЕКА}

сая [20, с. 186-187]. Наблюдение верно, но только для погребений с нишами-тайниками. Могилы с тайниками в дне ямы рассредоточены по территории Нижнего Поволжья и группируются в микрорегионах, где проводились наиболее интенсивные археологические исследования: на Иловле, левобережье Волги у Волгограда, Курмоярском Аксае, в зоне мелиорации в Астраханской и на юге Саратовской областей (рис. 1).

В небольшой группе погребений с тайниками в дне ямы можно отметить удивительное разнообразие форм могильных ям. Три из них совершены в квадратных ямах (рис. 2,1 ; рис. 3 , 2 ; рис. $\left.5,2^{3}\right)$, два - в широких прямоугольных (рис. 4,1 ; рис. 5,1 ), одно - в яме с заплечиками (рис. 3,1 ), еще два - в ямах с подбоями (рис. 2, 2; рис. 4,2$)^{4}$. При этом ориентировка погребенных во всех случаях - в южном секторе, отклонения от оси очень незначительны, что характерно для ранне- и среднесарматской культуры региона [20, с. 184, 276, рис. 50].

Исключение составляет только захоронение в кург. 1 могильника Горелый I. Поскольку в процессе раскопок точное расположение разбросанных грабителями костей человека на дне могильной ямы не фиксировалось, остается использовать те данные, которые на чертеже есть. К СЗ от центра ямы на фрагменте деревянных плах зафиксирована, судя по всему, грудная кость и ребро, а к ЮВ, также на плахе, - крестец. Под Ю-ЮВ стенкой лежали тазовая, бедренная и обломок, вероятно, большой берцовой кости.

Имеющихся данных достаточно, чтобы предположить, что погребенная женщина была ориентирована головой в северный сектор. Наиболее вероятным кажется положение по длинной оси ямы черепом на $\mathrm{C}-\mathrm{C} 3$. Согласно наблюдениям М.В. Кривошеева, с середины II века до н.э. пропорции квадратных ям с диагональным положением погребенного изменяются: они становятся широкими прямоугольными, положение погребенного трансформируется от диагонального на положение по длинной оси ямы с ориентировкой в северный сектор [8, с. 120]. Погребение из кург. 1 могильника Горелый I, самое позднее по времени захоронение в группе, точно соответствует всем этим критериям.

В проведенном ниже анализе использованы несколько методов научного археологичес- кого исследования. На стадии сбора и первичной обработки материала - метод внешней и внутренней критики источников, учитывающий личностные характеристики ученых. Метод первичной классификации на основе сходства объектов и традиционный метод сравнительной типологии использовались на этапе интерпретации. Это потребовало также применения классического метода широких аналогий с привлечением этнографических параллелей.

Анализ. Хронологически нижневолжские погребения с тайниками охватывают период от рубежа II - середины I в. до н.э., когда на ЮВ региона на правобережье Волги появляется самое раннее захоронение (Кривая Лука VIII, кург. 5/12), до середины - третьей четверти II в. н.э., когда на С3 в верховьях Медведицы совершается самое позднее (Горелый I, кург. 1/1). Отмечу, что самые поздние погребения бассейна Иловли и Медведицы совершены в квадратных ямах (рис. $1,1-3$ ) и относятся к числу как среднесарматских диагональных, ориентированных в южный сектор, так и позднесарматских с северной ориентировкой.

Тенденцию смещения погребений с тайниками к северо-западу подтверждают даты захоронений в Калиновском кург. 55/8 на левобережье Волги (рубеж эр - первая половина I в. н.э. [19, с. 105]), Аксае II кург. 34/1 (рубеж эр [3, с. 47]), Перегрузном кург. 51/2 (первая половина I в. н.э. [7, с. 86]), Киляковке кург. 1/4 (конец I- начало II в. н.э. [15, с. 247]), Авиловском II кург. 11/1 (І в. н.э. [14, с. 156]), Ютаевке кург. 30/1 (II в. н.э. [18, с. 102]). Последнее погребение обнаруживает любопытное сходство с Новолуганским - единственным захоронением с тайником в дне ямы к западу от Дона. В обоих есть архаичные формы железных предметов: в Ютаевском кург. 30/1 это - псалии, в Новолуганском - кинжал с антенновидным навершием рукояти $[24$, с. 85 , рис. 4,1$]$. Относительно кинжалов А.В. Симоненко высказал осторожное предположение, что к возрождению савроматской традиции антенновидного навершия у сарматов имеют отношение кочевники Средней Азии [16, c. 42]. Любопытно, что кинжал (меч?) с антенновидным навершием был найден в могильнике Заханата, кург. 2/1 в Калмыкии в яме с угловой нишей-тайником и без металлического котла $[30$, с. $72-73$, рис. 4,1$]$. 
Мне кажутся перспективными поиски прототипов S-видных псалиев с раскованными плоскими окончаниями и антенновидных наверший не только в Средней Азии, но и гораздо более восточных регионах. Если антенновидные навершия в курганах Горного Алтая также связывают с влиянием культур среднеазиатского (раннекушанского) круга [22, с. 32, 37], то S-видные- псалии с плоскими раскованными концами восходят к прототипам из могильников Синцьзяна последних веков до н.э. [22, с. 32 , рис. 1,43 ; с. 34$]^{5}$.

Обращает на себя внимание то обстоятельство, что захоронения с тайниками в дне ямы относятся к категории погребений с западными импортами и скромным количеством сопровождающих их предметов из золота, которые выделяются на фоне рядовых погребений своего времени, но не настолько, чтобы их можно было отнести к погребениям «элиты». Это подметил еще И.В. Сергацков, публикуя захоронение из Авиловского кург. 11/1. Труднее согласиться с интерпретацией могил с тайниками как погребений «домашних жриц и хозяек» [14, с. 157]. Из восьми нижневолжских погребений в трех похоронены мужчины, Новолуганское погребение - мужское, а определение пола погребенного в Горелом I не вызывает доверия. Кроме того, в тайниках найдены предметы, не ассоциирующиеся с хранительницей домашнего очага, например, фалары или импортная металлическая посуда. Не исключено, что котлы в тайниках связаны с определенными обрядовыми действиями, которые совершали похороненные в них кочевники. В самом раннем из рассмотренных здесь захоронений - в Кривой Луке - в котел был помещен деревянный ковш [23, с. 64]. Сочетание бронзового сосуда и деревянных предметов засвидетельствовано в процессе изготовления пьянящих сакральных напитков [4, с. 85]. Кочевники Евразии использовали для этого металлические котлы, Центральной Азии - литые на поддоне [5, с. 110-111], а в Восточной Европе, где была такая возможность, их заменяли коваными сосудами. Не исключено также то, что изготовление пьянящих напитков, в том числе сакральных, осуществлялось в бронзовых котлах, помещенных в тайники, а занимались этим погребенные, закрывающие собой указанные сакральные предметы.
Вернемся к статусу погребенных. Из восьми нижневолских могил ограблена только одна в могильнике Горелый І. Судя по картине ограбления, при которой на дне ямы были оставлены многочисленные кости скелета и разбитый сопровождающий инвентарь, совершали его в новое время. Прокопка грунта под нижней частью тела покойника, где, по мнению грабителей, могли быть ценные предметы, из-за чего тайник приобрел форму узкой короткой траншеи, не похожа на «почерк» древних грабителей. Последние хорошо знали где и что нужно искать. Сохранность могил с тайниками в дне ямы объясняется тем, что, имея по роду своих занятий близкое отношение к племенной верхушке, погребенные в них не являлись элитой кочевников. В их могилах и грабить-то было нечего.

Погребение такого класса, опубликованное Я. Шустером, очень точно было названо им погребением «бедного князя» [31, S. 149]. Погребения сарматских «бедных князей», а к ним относятся не только могилы с тайниками, выкопанными в дне ямы, но и погребения условного «среднего класса» с набором статусных, но не дорогих предметов, заслуживают отдельного специального исследования.

Результаты. Обряд размещения тайника в дне могильной ямы специфичен для сарматских погребений Нижнего Поволжья и существует с рубежа II - середины I в. до н.э., до середины - третьей четверти II в. н.э. Самые ранние погребения находятся на ЮВ региона, к концу периода они смещаются на СЗ. Изменяется конструкция ямы: прямоугольные ямы и ямы с подбоем уступают место квадратным.

Найденные в тайниках котлы связаны с определенными обрядовыми действиями, которые совершали похороненные в них кочевники. Известно, что бронзовые литые котлы использовались для изготовления пьянящих напитков, в том числе сакральных.

Захоронения с тайниками в дне ямы не отличаются особым богатством инвентаря, о них вряд ли можно говорить как о погребениях «элиты», условно их можно назвать «средним классом». Культура этой социальной страты требует специального исследования хотя бы потому, что часть найденных в ее погребениях предметов находит аналогии в памятниках Внутренней Азии, и может дать дополнительные данные о миграциях эпохи раннего железного века. 


\section{ПРИМЕЧАНИЯ}

1 Работа выполнена при поддержке программы фундаментальных научных исследований государственных академий наук на 2013-2020 гг. в рамках базовой темы НИР «Изучение межкультурных взаимодействий населения Нижнего Дона с древнейших времен до нового времени», № 01201354248.

The work was supported by the program of fundamental scientific research of state academies of sciences for 2013-2020 in the framework of basic research topic "Study of the Intercultural Interactions of the Population of the Lower Don from Ancient Times to the New Age", state registration no. 01201354248.

2 План погребения в Жутовском кург. 28 [29, c. 186 , рис. 8,1$]$ искажен. Ниши имеют иную форму и расположены в южных углах могильной ямы (ср.: [27, с. 116]).

3 В полевом отчете об исследованиях кург. 1 могильника Горелый I погребение описано как «яма с широкими заплечиками», а само захоронение было совершено в узкой могильной яме [21, c. 3]. Некоторые детали конструкции заставляют предположить неверную интерпретацию раскопанного объекта. Во-первых, это неправдоподобно широкие заплечики, к тому же окружающие яму с четырех сторон. Во-вторых, столь же невероятный размер имеет могильная яма $-1,0 \times 0,45$ м. В такой яме можно было захоронить ребенка 6-7 лет, но не ту «взрослую женщину», кости которой были разбросаны на заплечиках [21, с. 3]. Один раз, впрочем, автор проговаривается, указывая глубину дна погребения равной глубине заплечиков - «3,143,17 м от условного центра кургана» [21 с. 3]

Мне представляется, что погребение было совершено в яме широкой прямоугольной, почти квадратной формы. По ее дну и были разбросаны кости погребенной, а «могильная яма» в центре это расширенная грабителями яма-тайник. На фото $[21$, рис. 36$]$ и плане $[21$, с. 31 , л. 6] хорошо видно, что северная часть углубления имеет правильную полукруглую форму с расширенной воронковидной верхней частью стенок. Конфигурация длинных стенок и южной половины ямы, как они показаны на чертеже, совершенно не совпадают (при всех искажениях перспективы на снимке) с тем, что видно на фото. На плане (рис. 5, 2) зеленым показан примерный контур, восстановленный по снимку, и фиолетовым - реконструируемая яма-тайник. Размеры ее: диаметр по верхнему краю - 0,5 м, по дну - 0,35 см соответствуют обычному среднему размеру тайников.

Вообще, отчет изобилует неточностями, свидетельствующими о низком уровне как проведенных раскопок, так и фиксации результатов. В описании скругленные северная и С3 стенки ямы названы СВ [21, с. 3], в профилях бровок [21, c. 19, л. 4] мне не удалось отыскать «выкид из грабительского лаза», внесенный в условные обозначения, в котором якобы были сделаны многочисленные находки. На фото [21, рис. 52 и 53] обломки бронзовых и керамических сосудов аккуратно разложены на поверхности, подчищенной после скрепера, которым они и были разрушены. Фразу «У юго-восточной стенки $<\ldots>$ по всему периметру ямы фиксировались заплечики» оставляю без комментариев: моя статья не является рецензией на полевой отчет. Все эти, и целый ряд иных ошибок в описании, а также неверные интерпретации, к сожалению, перешли в единственную публикацию памятника [1, с. 8-22].

${ }^{4}$ Кривая Лука VII, кург. 5, погр. 12. Необычная форма могильной ямы с широким «заплечиком» вдоль одной из стенок, плахи на «заплечике», лежащие по длинной оси ямы, и неглубокий подбой, зафиксированный на восточной стенке (рис. 2, 2, план и профиль), позволяют реконструировать могильную яму и ее сооружение следующим образом. Прямоугольной формы яма с заплечиками, в которой было совершено раннее погребение (рис. 2, 2, на профиле А-А показана зеленым), была прокопана до уровня заплечика, после чего в западной половине углублена до уровня дна, где разрушила двойное погребение - в заполнении встречались обломки бронзового котла, керамика, костяная рукоять ножа (?) с резьбой в зверином стиле, кости скелета взрослого и отдельные кости детского скелета [22, с. 61]. В западной части дна сделано углубление и под западной стенкой устроен подбой (рис. 2, 2, на профиле А-А показан фиолетовым). Продольное направление плах на заплечике и то, что кости погребенных находились под ними, можно объяснить тем, что между захоронениями прошло немного времени и плахи еще можно было передвинуть.

Аксай II, кург. 34, погр. 1. В подбое, устроенном в восточной стенке ямы, было совершено и это погребение. От подбоя сохранился выступ материкового суглинка на восточной стенке, который не может быть частью «заплечика, частично оплывшего» [2, с. 45-46], хотя бы потому что находится на 0,5 м выше «заплечика» (ступеньки. - Б. Р.) на западной стенке ямы. Свод подбоя, вероятно, обрушился, его восточный край был ближе к высокой вертикальной западной ступеньке. Неудобства, которые создавала такая конструкция, видимо, послужили причиной того, что покойный был оставлен в необычной позе на правом боку спиной к ступеньке.

5 Выражаю искреннюю признательность профессору А.В. Тишкину (г. Барнаул) за консультацию и возможность использовать его фотографию из Музея Терракотовой армии Цинь в Сиане. 


\section{ПРИЛОЖЕНИЕ}

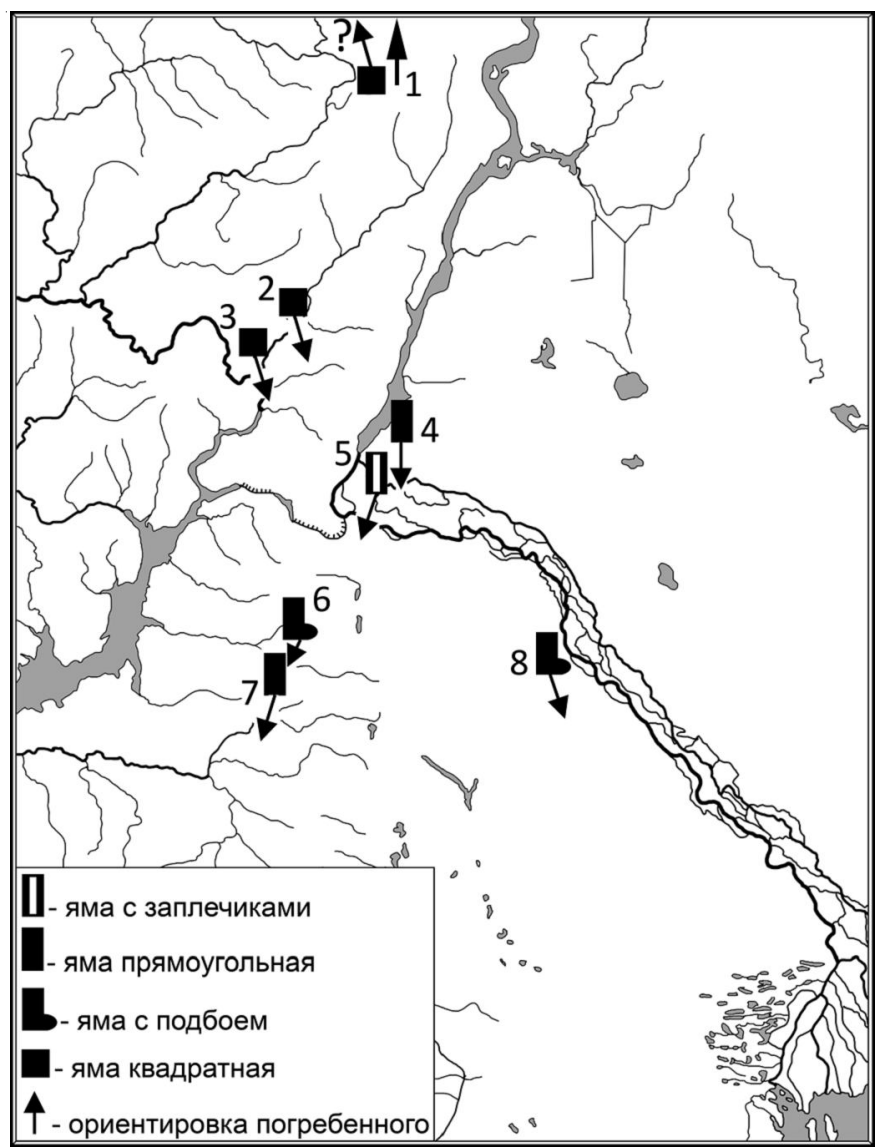

Рис. 1. Карта сарматских погребений с тайниками в дне ямы в могильниках Нижнего Поволжья (без масштаба):

1 - Горелый I, кург. 1, погр. 1; 2 - Ютаевский, кург. 30, погр. 1; 3 - Авиловский II, кург. 11, погр. 1; 4 - Калиновский, кург. 55, погр. 8; 5 - Киляковка, кург. 1, погр. 4; 6 - Аксай II, кург. 34, погр. 1; 7 - Перегрузное I, кург. 51, погр. 2; 8 - Кривая Лука VIII, кург. 5, погр. 12

Fig. 1. Map of Sarmatian graves with hiding-holes in the bottom of the pit in the kurgans of the Lower Volga region (no scale):

1 - Gorelyi I, kurgan 1, grave 1; 2 - Yutaevskiy, kurgan 30, grave 1; 3 - Avilovskiy II, kurgan 11, grave 1; 4 - Kalinovskiy, kurgan 55, grave 8; 5 - Kilyakovka, kurgan 1, grave 4; 6 - Aksai II, kurgan 34, grave 1;

7 - Peregruznoe I, kurgan 51, grave 2; 8 - Krivaya Luka VIII, kurgan 5, grave 12 


\section{АРХЕОЛОГИЯ РАННЕГО ЖЕЛЕЗНОГО ВЕКА}
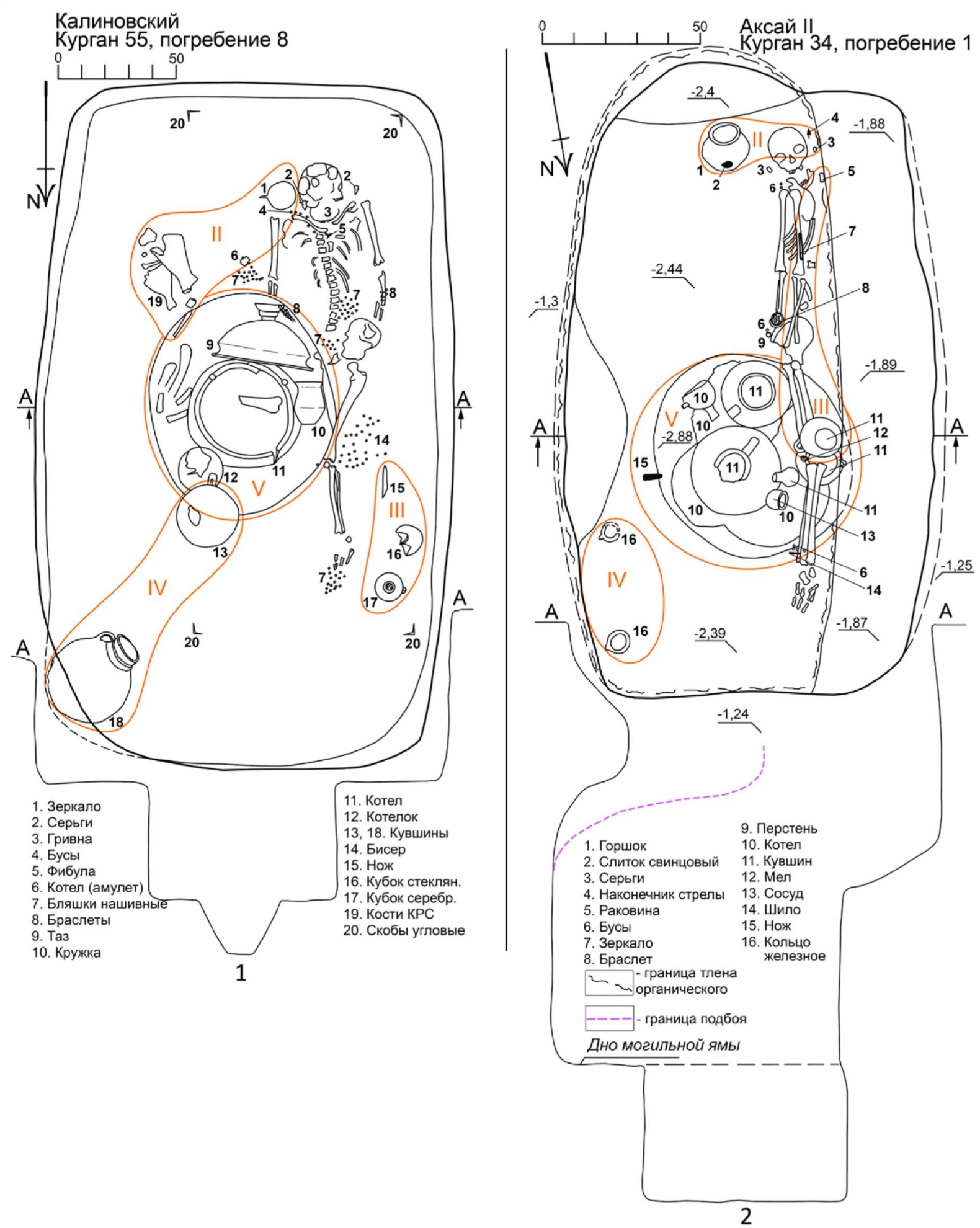

Рис. 2. Планы и разрезы погребений с тайниками:

1 - Калиновский, кург. 55, погр. 8 (по: [26, л. 29]); 2 - Аксай II, кург. 34, погр. 1 (по: [2, рис. 246])

Fig. 2. Plans and cross-sections of graves with hiding-holes:

1 - Kalinovskiy, kurgan 55, grave 8 (after: [26, 1. 29]); 2 - Aksai II, kurgan 34, grave 1 (after: [2, fig. 246]) 

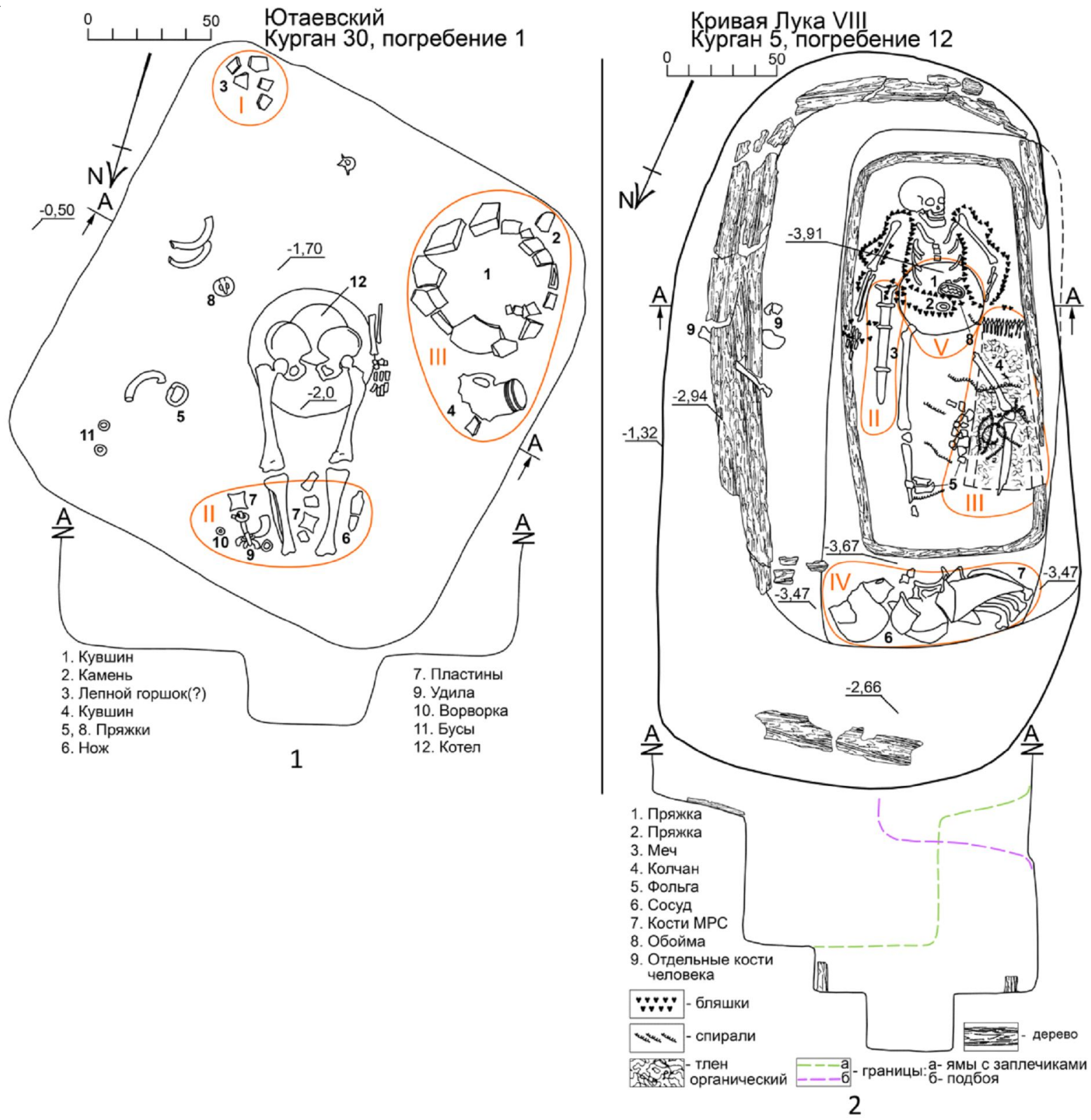

Рис. 3. Планы и разрезы погребений с тайниками:

1 - Ютаевский, кург. 30, погр. 1 (по: [17, рис. 77]); 2 - Кривая Лука VIII, кург. 5, погр. 12 (по: [23, том 2, рис. 63])

Fig. 3. Plans and cross-sections of graves with hiding-holes:

1 - Yutaevskiy, kurgan 30, grave 1 (after: [17, fig. 77]); 2 - Krivaya Luka VIII, kurgan 5, grave 12 (after: [23, vol. 2, fig. 63])

Примечание. Компьютерная графика рисунков 1-5 и дополнения на рисунках 2, 2, 3, 2 и 5, 2 - автора. Note. Computer drawing in figures 1-5, and reconstructions in figures 2, 2, 3, 2 and 5, 2 by the author. 


\section{АРХЕОЛОГИЯ РАННЕГО ЖЕЛЕЗНОГО ВЕКА}
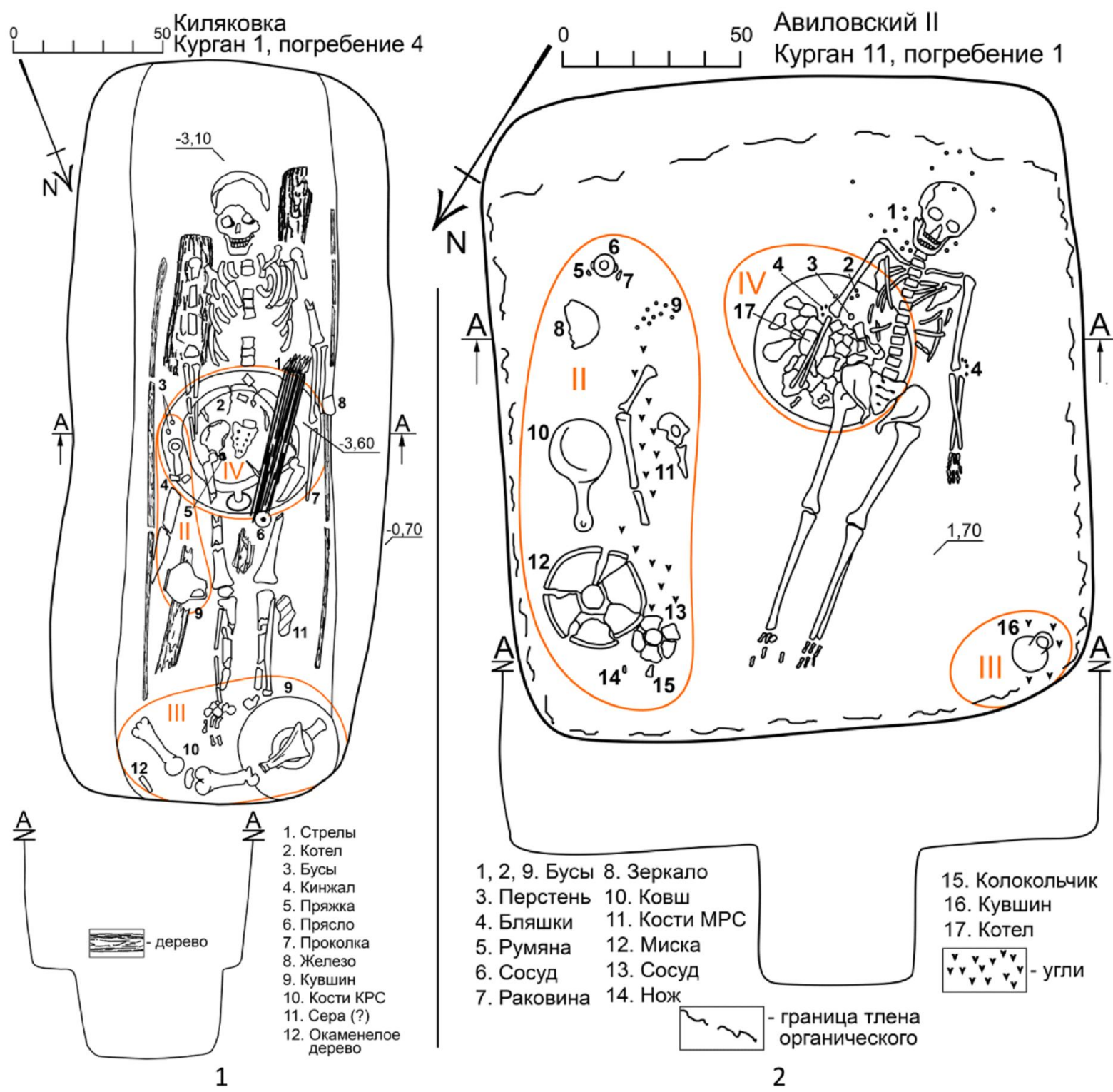

Рис. 4. Планы и разрезы погребений с тайниками:

1 - Киляковка, кург. 1, погр. 4 (по: [11, рис. 5]); 2 - Авиловский II, кург. 11, погр. 1 (по: [13, рис. 97])

Fig. 4. Plans and cross-sections of graves with hiding-holes:

1 - Kilyakovka, kurgan 1, grave 4 (after: [11, fig. 5]); 2 - Avilovskiy II, kurgan 11, grave 1 (after: [13, fig. 97]) 

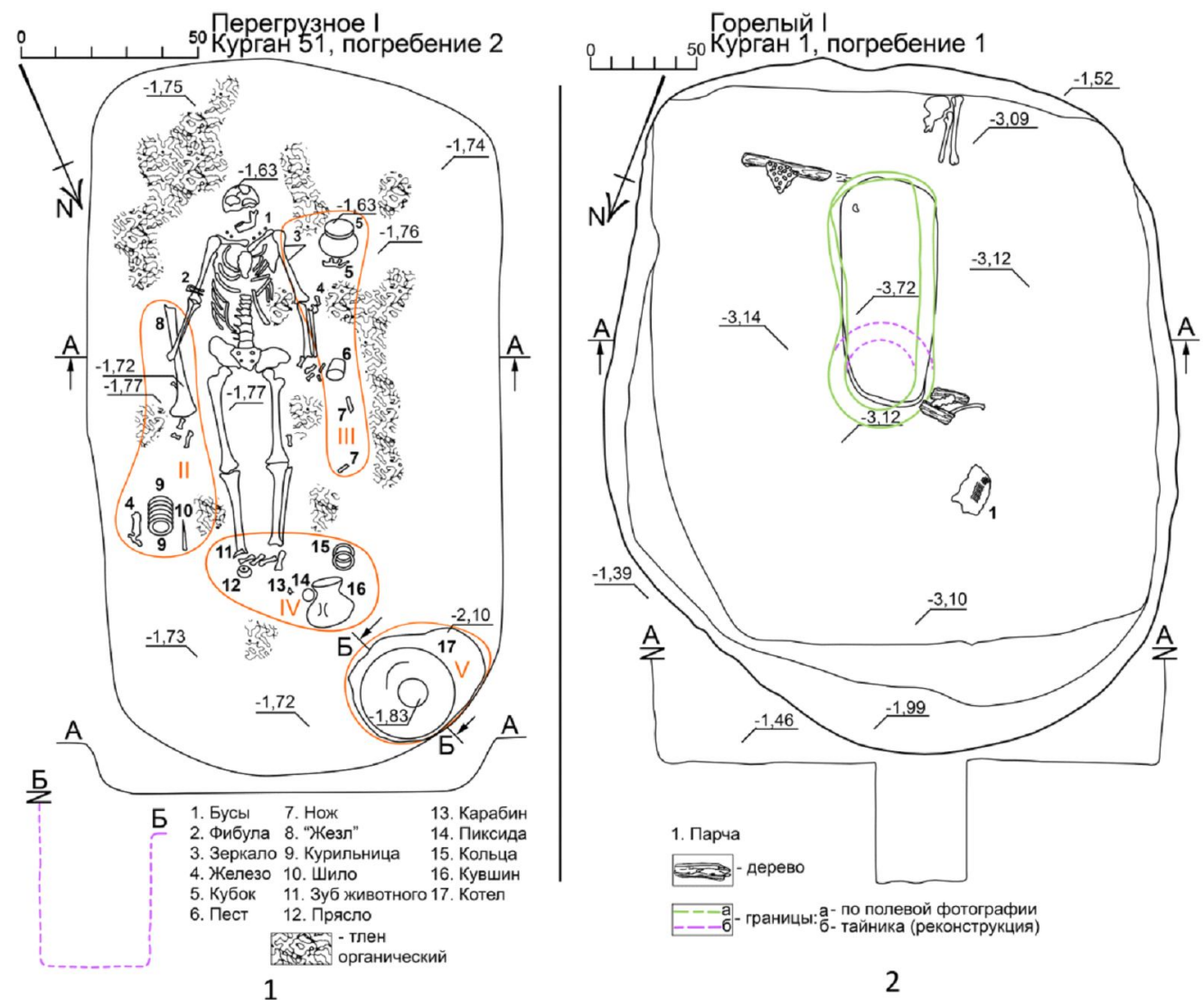

1

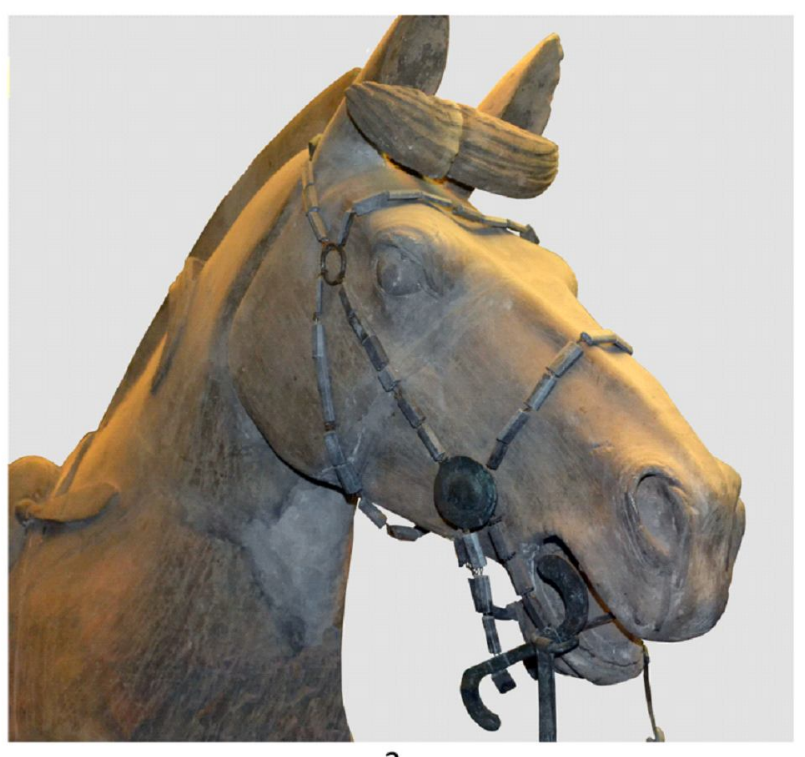

3

Рис. 5. Планы и разрезы погребений с тайниками:

1 - Перегрузное I, кург. 51, погр. 2 (по: [6, рис. 110]); 2 - Горелый I, кург. 1, погр. 1 (по: [21, с. 31, л. 6]); 3 -S-видные псалии на терракотовой скульптуре коня из мавзолея Цинь Шихуанди

Fig. 5. Plans and cross-sections of graves with hiding-holes:

1 - Peregruznoe I, kurgan 51, grave 2 (after: [6, fig. 110]; 2 - Gorelyi I, kurgan 1, grave 1 (after: [21, p. 31, 1. 6]); 3 - S-shaped cheek-pieces on a horse terracotta sculpture of the Qin Shihuandi Mausoleum

Примечание. Фото скульптуры коня - А.А. Тишкин (с разрешения автора).

Note. Photo of the sculpture by A.A. Tishkin (reprinted by permission of the author). 


\section{СПИСОК СОКРАЩЕНИЙ}

ВОКМ - Волгоградский областной краеведческий музей.

ИА РАН - Институт археологии Российской академии наук.

ИИМК РАН - Институт истории материальной культуры Российской академии наук.

КСИА - Краткие сообщения Института археологии.

$P A-$ Российская археология.

$C A-$ Советская археология.

\section{СПИСОК ЛИТЕРАТУРЫ}

1. Балановский, А. В. Погребение знатной сарматки из курганного могильника «Горелый І» / А. В. Балановский, В. В. Тихонов // Наша малая Родина: ее история, развитие, проблемы. - Балашов : Николаев О.А., 2009. - С. 8-22.

2. Дьяченко, А. Н. Отчет о проведении археологических исследований курганных могильников Аксай II и Аксай III в зоне строительства газопровода на территории Октябрьского района Волгоградской области в 2006 г. - Волгоград, 2007 / А. Н. Дьяченко // Архив ВОКМ. - № 247, 247a.

3. Дьяченко, А. Н. Раскопки курганных могильников Аксай II и Аксай III у села Аксай Октябрьского района Волгоградской области (к вопросу об экономических связях сарматского населения ВолгоДонского региона) / А. Н. Дьяченко, А. С. Скрипкин, В. И. Моисеев // Материалы по археологии ВолгоДонских степей / отв. ред. А. С. Скрипкин. - Волгоград : Изд-во Волгогр. ин-та управления - филиала РАНХиГС, 2017. - Вып. 4. - С. 8-82.

4. Ермоленко, Л. Н. К вопросу о назначении «скифских» котлов (на материалах Центральной Азии) / Л. Н. Ермоленко // Скифо-сибирский мир (социальная структура и общественные отношения). В 2 ч. Ч. 2 / отв. ред. В. Н. Добжанский. - Кемерово : Изд-во Кемер. гос. ун-та, 1989. - С. 83-86.

5. Ермоленко, Л. Н. О ритуальных сосудах для сакральных напитков у древних кочевников (сосуды на поддоне) / Л. Н. Ермоленко // Вопросы археологии Казахстана / отв. ред. 3. Самашев. - Алматы ; М. : Гылым, 1998. - Вып. 2. - С. 110-116.

6. Клепиков, В. М. Отчет о проведении археологических исследований курганного могильника Перегрузное I у с. Перегрузное Октябрьского района Волгоградской области в 2011 году. - Волгоград, 2012 / В. М. Клепиков // Архив ВОКМ. - № 288, 288 .

7. Клепиков, В. М. Археологические исследования курганного могильника Перегрузное I / В. М. Клепиков // Курганный могильник Перегрузное I: результаты междисциплинарных исследова- ний / научн. ред.: М. А. Балабанова, В. М. Клепиков, А. С. Скрипкин. - Волгоград : Изд-во Рос. академии нар. хоз-ва и гос. службы, 2014. - С. 9-217.

8. Кривошеев, М. В. Хронология позднесарматской культуры Нижнего Поволжья / М. В. Кривошеев // Сарматские культуры Евразии: проблемы региональной хронологии / отв. ред. Б. А. Раев. - Краснодар : Наследие Кубани ; Куб. гос. ун-т, 2004. - C. 117-126.

9. Мордвинцева, В. И. Набор серебряной посуды из курганного могильника Жутово / В. И. Мордвинцева // РА. - 2000. - № 1. - С. 144-153.

10. Мордвинцева, В. И. Полихромный звериный стиль / В. И. Мордвинцева. - Симферополь : Универсум, 2003. - 216 с.

11. Мыськов, Е. П. Отчет о раскопках курганов у с. Киляковка Среднеахтубинского района Волгоградской области, проведенных Волго-Ахтубинским отрядом археологической экспедиции ВолГПИ в 1984 году. - Волгоград, 1985 / Е. П. Мыськов // Архив ВОКМ. - № 45, 45a.

12. Мыськов, Е. П. Погребение сарматской знати с Есауловского Аксая / Е. П. Мыськов, А. В. Кияшко, А. С. Скрипкин // Нижневолжский археологический вестник. - 1999. - Вып. 2. - С. 149-167.

13. Сергацков, И. В. Отчет о раскопках Иловлинской археологической экспедиции ВолГУ в 1991 г. - Волгоград, 1992 / И. В. Сергацков // Архив BОКМ. - № 81, 81a.

14. Сергацков, И. В. Сарматское погребение с римским импортом в низовьях Иловли / И. В. Сергацков // РА. - 1998. - № 4. - С. 150-159.

15. Сергацков, И. В. Бронзовый котел из Киляковки (работа над ошибками) / И. В. Сергацков // Нижневолжский археологический вестник. 2006. - Вып. 8. - С. 246-248.

16. Симоненко, А. В. Сарматские всадники Северного Причерноморья / А. В. Симоненко. -Киев : Олег Филюк, 2015. - 466 с.

17. Скрипкин, А. С. Отчет по раскопкам курганного могильника, расположенного у хутора Ютаевки Иловлинского района Волгоградской области. - Волгоград, 1968 / А. С. Скрипкин // Архив ИА РАН. - Ф-1. - Р-1. - № 3489, 3489а.

18. Скрипкин, А. С. Раскопки курганов на Иловле / А. С. Скрипкин // Историко-краеведческие записки. - Волгоград : Нижневолж. книж. изд-во, 1973. - Вып. 1. - С. 95-109.

19. Скрипкин, А. С. Фибулы Нижнего Поволжья (поматериалам сарматских погребений) / А. С. Скрипкин// СА. - 1977. - № 2. - С. 100-120.

20. Скрипкин, А. С. Азиатская Сарматия. Проблемы хронологии и ее исторический аспект / А. С. Скрипкин. - Саратов : Изд-во Сарат. ун-та, 1990.-299 с.

21. Тихонов, В. В. Отчет на тему «Об археологических исследованиях курганных могильников у села 
Широкий Карамыш Лысогорского района Саратовской области в зоне строительства газопровода Починки-Изобильное-Северо-Ставропольское ПХГ в 2003 г.». - Саратов, 2004 / В. В. Тихонов // Архив ИА РАН. - Ф-1. - Р-1. - № 48730-48739.

22. Тишкин, А. А. Горный Алтай в хуннское время: культурно-хронологический анализ археологических материалов / А. А. Тишкин, В. В. Горбунов // РА. - 2006. - № 3. - С. 31-40.

23. Федоров-Давыдов, Г. А. Отчет о раскопках курганов в урочище «Кривая Лука» в Черноярском районе Астраханской области в 1974 г. Т. 1, 2, 3. Москва, 1975 / Г. А. Федоров-Давыдов, В. В. Дворниченко, Н. В. Малиновская // Архив Астраханского музея-заповедника. - (Без инв. номера).

24. Шаповалов, Т. О. Сарматські поховання поблизу с. Новолуганське / Т. О. Шаповалов //Археологія. 1973. - № 8. - С. 82-88.

25. Шилов, В. П. Отчет о раскопках Калиновского отряда Сталинградской археологической экспедиции ИИМК АН СССР. - Ленинград, 1955 / В. П. Шилов // Архив ВОКМ.- № 7,7a.

26. Материалы раскопок Калиновского могильника: полевые чертежи. - Ленинград, 1954 // Архив ИИМК РАН. - Ф.- 35. - 1954. - Д. 161.

27. Шилов, В. П. Отчет о работах Астраханской экспедиции за 1964 год. - Ленинград, 1965 / В. П. Шилов // Архив ИА РАН. - Ф-1. - Р-1. - № 3156.

28. Шилов, В. П. К проблеме взаимоотношений кочевых племен и античных городов Северного Причерноморья в сарматскую эпоху / В. П. Шилов // КСИА. - 1973. - Вып. 138. - С. 60-65.

29. Шилов, В. П. Запорожский курган (К вопросу о погребениях аорсской знати) / В. П. Шилов // CA. - 1983. - № 1. - С. 178-192.

30. Шнайдштейн, Е. В. Раскопки курганной группы Заханата / Е. В. Шнайдштейн // Древности Калмыкии / отв. ред. Е. В. Цуцкин. - Элиста : Калмыц. науч.-исслед. ин-т истории, филологии, экономики, 1985. - С. 70-93.

31. Schuster, J. Der arme Fürst. Ein bescheiden ausgestattetes Prunkgrab der älteren Kaiserzeit von Zgliczyn Pobodzy, Nordmasowien (Polen) / J. Schuster // Germania. -2016. -Jg. 94:1-2. - S. 117-157.

\section{REFERENCES}

1. Balanovskiy A.V., Tikhonov V.V. Pogrebenie znatnoy sarmatki iz kurgannogo mogilnika «Gorelyy I» [Grave ofa Noble Sarmatian Woman of the Kurgan Cemetery Gorelyi-I]. Nasha malaya Rodina: ee istoriya, razvitie, problemy [Our Native Land: Its History, Development, Problems]. Balashov, NikolaevO.A., 2009, pp. 8-22.

2. Dyachenko A.N. Otchet o provedenii arkheologicheskikh issledovaniy kurgannykh mogilnikov Aksay II i Aksay III v zone stroitelstva gazoprovoda na territorii Oktyabrskogo rayona Volgogradskoy oblasti v 2006 g. - Volgograd, 2007 [Report on Archaeological Research of Aksai II and Aksai III Kurgan Cemeteries in the Pipeline Construction Zone on the Territory of Oktiabrskiy District of Volgograd Region in 2006. Volgograd, 2007]. Arkhiv VOKM [Archive of the Volgograd Regional Museum of Local Lore], no. 247, 247a.

3. Dyachenko A.N., Skripkin A.S., Moiseev V.I. Raskopki kurgannykh mogilnikov Aksay II i Aksay III u sela Aksay Oktyabrskogo rayona Volgogradskoy oblasti (k voprosu ob ekonomicheskikh svyazyakh sarmatskogo naseleniya Volgo-Donskogo regiona) [Excavations of Kurgan Cemeteries Aksai II and Aksai III near the Village of Aksai, Oktyabrsky District, Volgograd Region (On Economic Relations of the Sarmatian Tribes of the Volga-Don Region)]. Skripkin A.S., ed. Materialy po arkheologii Volgo-Donskikh stepey [Materials on the Archeology of the Volga-Don Steppes]. Volgograd, Izd-vo Volgogradskogo instituta upravleniya - filiala RANKhiGS, 2017, iss. 4, pp. 8-82.

4. Ermolenko L.N. K voprosu o naznachenii «skifskikh» kotlov (na materialakh Tsentralnoy Azii) [To the Using of "Scythian" Cauldrons (After Data of Central Asia)]. Dobzhansky V.N., ed. Skifo-sibirskiy mir (sotsialnaya struktura i obshchestvennye otnosheniya). V 2 ch. Ch. 2 [Scythian-Siberian World (Social Structure and Social Relations). In 2 Parts. Part 2]. Kemerovo, Izd-vo Kemerovskogo gosudarstvennogo universiteta, 1989, pp. 83-86.

5. Ermolenko L.N. O ritualnykh sosudakh dlya sakralnykh napitkov u drevnikh kochevnikov (sosudy na poddone) [On Ritual Vessels for Sacred Drinks of Ancient Nomads (Vessels on Stand)]. Samashev Z., ed. Voprosy Arkheologii Kazakhstana [Kazakhstan Archaeology Issues]. Almaty, Moscow, Gylym Publ., 1998, iss. 2, pp. 110-116.

6. Klepikov V.M. Otchet o provedenii arkheologicheskikh issledovaniy kurgannogo mogilnika Peregruznoe I u s. Peregruznoe Oktyabrskogo rayona Volgogradskoy oblasti v 2011 godu. - Volgograd, 2012 [Report on the Archaeological Research of the Peregruznoe Kurgan Cemetery near Peregruznoe Village in Oktyabrskii District of Volgograd Region in 2011. Volgograd, 2012]. Arkhiv VOKM [Archive of the Volgograd Regional Museum of Local Lore], no. 288, 288a.

7. Klepikov V.M. Arkheologicheskie issledovaniya kurgannogo mogilnika Peregruznoe I [Archaeological Research of the Kurgan Cemetery Peregruznoe I]. Balabanova M.A., Klepikov V.M., Skripkin A.S., eds. Kurgannyy mogilnik Peregruznoe I: rezultaty mezhdistsiplinarnykh issledovaniy [Kurgan Cemetery Peregruznoe I: Results of Interdisciplinary Research]. Volgograd, Izd-vo Rossiyskoy akademii 
narodnogo khozyaystva i gosudarstvennoy sluzhby, 2014, pp. 9-217.

8. Krivosheev M.V. Khronologiya pozdnesarmatskoy kultury Nizhnego Povolzhya [Chronology of the Late Sarmatian Culture in the Lower Volga Region]. Raev B.A., ed. Sarmatskie kultury Evrazii: problemy regionalnoy khronologii [Sarmatian Cultures of Eurasia: Problems of Regional Chronology]. Krasnodar, Nasledie Kubani Publ., Kubanskiy gosudarstvennyy universitet, 2004, pp. 117-126.

9. Mordvintseva V.I. Nabor serebryanoy posudy iz kurgannogo mogilnika Zhutovo [A Set of Silver Vessels from Sarmatian Kurgan No 28 of the Zhutovo Cemetery]. RA [Russian Archaeology], 2000, no. 1, pp. 144-153.

10. Mordvintseva V.I. Polikhromnyy zverinyy stil [Polychrome Animal Style]. Simferopol, Universum Publ., 2003. 216 p.

11. Myskov E.P. Otchet o raskopkakh kurganov u s. Kilyakovka Sredneakhtubinskogo rayona Volgogradskoy oblasti, provedennykh VolgoAkhtubinskim otryadom arkheologicheskoy ekspeditsii VolGPI v 1984 godu. - Volgograd, 1985 [Report on Excavation of Kurgans near the Village of Kilyakovka of Sredneakhtubinski District of Volgograd Region Carried Out by the Volga-Akhtubinskiy Division of the Archaeological Expedition of Volgograd State Pedagogical Institute in 1984. Volgograd, 1985]. Arkhiv VOKM [Archive of the Volgograd Regional Museum of Local Lore], no. 45, 45a.

12. Myskov E.P., Kiyashko A.V., Skripkin A.S. Pogrebenie sarmatskoy znati s Esaulovskogo Aksaya [Grave of the Sarmatian Nobility from Esaulovsky Aksay]. Nizhnevolzhskiy arkheologicheskiy vestnik [The Lower Volga Archaeological Bulletin], 1999, iss. 2, pp. 149-167.

13. Sergatskov I.V. Otchet o raskopkakh Ilovlinskoy arkheologicheskoy ekspeditsii VolGU v 1991 g. - Volgograd, 1992 [Report on the Excavations of the Ilovlinskaya Archaeological Expedition of Volgograd State University in 1991. Volgograd, 1992]. Arkhiv VOKM [Archive of the Volgograd Regional Museum of Local Lore], no. 81, 81a.

14. Sergatskov I.V. Sarmatskoe pogrebenie s rimskim importom v nizovyakh Ilovli [Sarmatian Grave with Roman Imports in the Lower Ilovlia Region]. $R A$ [Russian Archaeology], 1998, no. 4, pp. 150-159.

15. Sergatskov I.V. Bronzovyy kotel iz Kilyakovki (rabota nad oshibkami) [Bronze Cauldron from Kilyakovka (Error Corrections)]. Nizhnevolzhskiy arkheologicheskiy vestnik [The Lower Volga Archaeological Bulletin], 2006, iss. 8, pp. 246-248.

16. Simonenko A.V. Sarmatskie vsadniki Severnogo Prichernomorya [Sarmatian Horsemen of the North Pontic Region]. Kiev, Oleg Filyuk Publ., 2015.466p.
17. Skripkin A.S. Otchet po raskopkam kurgannogo mogilnika, raspolozhennogo u khutora Yutaevki Ilovlinskogo rayona Volgogradskoy oblasti. - Volgograd, 1968 [Report on Excavations of the Kurgan Cemetery near Yutaevka Khutor in Ilovlinsky District of Volgograd Region. Volgograd, 1968]. Arkhiv IA RAN [Archive of the Institute of Archeology of the Russian Academy of Sciences], F-1, R-1, no. 3489, 3489a.

18. Skripkin A.S. Raskopki kurganov na Ilovle [Excavations of Kurgans in the Ilovlja Basin]. Istorikokraevedcheskie zapiski [Notes on Local History]. Volgograd, Nizhnevolzhskoe knizhnoe izd-vo, 1973, iss. 1, pp. 95-109.

19. Skripkin A.S. Fibuly Nizhnego Povolzhya (po materialam sarmatskikh pogrebeniy) [Fibulae of the Lower Volga Region (On Materials of Sarmatian Graves)]. $S A$ [Soviet Archaeology], 1977, no. 2, pp. 100-120.

20. Skripkin A.S. Aziatskaya Sarmatiya. Problemy khronologii i ee istoricheskiy aspekt [Asian Sarmatia. Problems of Chronology and Its Historical Aspect]. Saratov, Izd-vo Saratovskogo universiteta, 1990. 299 p.

21. Tikhonov V.V. Otchet na temu «Ob arkheologicheskikh issledovaniyakh kurgannykh mogilnikov u sela Shirokiy Karamysh Lysogorskogo rayona Saratovskoy oblasti v zone stroitelstva gazoprovoda Pochinki-Izobilnoe-SeveroStavropolskoe PKhG v 2003 g.». - Saratov, 2004 [Report on the Issue "On Archaeological Research of Kurgans near the Village of Shirokiy Karamysh of Lysogorski District of Saratov Region in the Pipeline Construction Zone of the Pochinki-Izobilnoye-SeveroStavropolskoye Gas Storage Facility in 2003". Saratov, 2004]. Arkhiv IA RAN [Archive of the Institute of Archeology of the Russian Academy of Sciences], F-1, R-1, no. 48730-48739.

22. Tishkin A.A., Gorbunov V.V. Gornyy Altay v khunnskoe vremya: kulturno-khronologicheskiy analiz arkheologicheskikh materialov [The Altai Mountains in the Hunnian Period: Cultural and Chronological Analysis of Archaeological Data]. RA [Russian Archaeology], 2006, no. 3, pp. 31-40.

23. Fedorov-Davydov G.A., Dvornichenko V.V., Malinovskaya N.V. Otchet o raskopkakh kurganov v urochishche «Krivaya Luka» v Chernoyarskom rayone Astrakhanskoy oblasti v 1974 g. T. 1, 2, 3. - Moskva, 1975 [Report on Excavations of Kurgans in the Place of Krivaya Luka of Chernoyarsk District of Astrakhan Region in 1974. Volumes 1,2,3. Moscow, 1975]. Arkhiv Astrakhanskogo muzeya-zapovednika [Archive of the Astrakhan Museum-Reserve]. (No inventory number).

24. Shapovalov T.O. Sarmatski pokhovannya poblizu s. Novoluganske [Sarmatian Graves near the Village Novoluganske]. Arkheologiya, 1973, no. 8, pp. 82-88. 
25. Shilov V.P. Otchet o raskopkakh Kalinovskogo otryada Stalingradskoy arkheologicheskoy ekspeditsii IIMK AN SSSR. - Leningrad, 1955 [Report on Excavations of the Kalinovsky Division of the Stalingrad Archaeological Expedition of the Institute of the History of Material Culture of the USSR Academy of Sciences. Leningrad, 1955]. Arkhiv VOKM [Archive of the Volgograd Regional Museum of Local Lore], no.7, 7a.

26. Materialy raskopok Kalinovskogo mogilnika: polevye chertezhi. - Leningrad, 1954 [Excavation Materials of the Kalinovsky Kurgan Cemetery. Field Drawings. Leningrad, 1955]. Arkhiv IIMK RAN [Archive of the Institute of the History of Material Culture of the Russian Academy of Sciences], F. 35, 1954. D. 161.

27. Shilov V.P. Otchet o rabotakh Astrakhanskoy ekspeditsii za 1964 god. - Leningrad, 1965 [Report on Field Works of the Astrakhan Expedition of 1964. Leningrad, 1965]. Arkhiv IA RAN [Archive of the Institute of Archeology of the Russian Academy of Sciences], F-1, R-1, no. 3156.
28. Shilov V.P. K probleme vzaimootnosheniy kochevykh plemen i antichnykh gorodov Severnogo Prichernomorya $\mathrm{v}$ sarmatskuyu epokhu [On the Problem of the Relations of Nomadic Tribes and Ancient Cities of the Northern Black Sea Region in the Sarmatian Era]. KSIA [Brief Communications of the Institute of Archaeology], 1973, iss. 138, pp. 60-65.

29. Shilov V.P. Zaporozhskiy kurgan (K voprosu o pogrebeniyakh aorsskoy znati) [Zaporozhie Kurgan (To the Problem of Aorsian Nobility Graves)]. SA [Soviet Archaeology], 1983, no. 1, pp. 178-192.

30. Shnaidshtein E.V. Raskopki kurgannoy gruppy Zakhanata [Excavations of Kurgan CemeteryZakhanata]. Tsutskin E.V., ed. Drevnosti Kalmykii [Antiquities of Kalmykia]. Elista, Kalmytskiy nauchno-issledovatelskiy institut istorii, filologii, ekonomiki, 1985, pp. 70-93.

31. Schuster J. Der arme Fürst. Ein bescheiden ausgestattetes Prunkgrab der älteren Kaiserzeit von Zgliczyn Pobodzy, Nordmasowien (Polen). Germania, 2016, Jg. 94:1-2, S. 117-157.

\section{Information About the Author}

Boris A. Raev, Candidate of Sciences (History), Senior Researcher, Laboratory of Archeology, Federal Research Centre The Southern Scientific Centre of the Russian Academy of Sciences, Chekhov St, 41, 344006 Rostov-on-Don, Russian Federation, boris_raev@mail.ru, https://orcid.org/0000-0001-6006-6173

\section{Информация об авторе}

Борис Аронович Раев, кандидат исторических наук, старший научный сотрудник лаборатории археологии, Федеральный исследовательский центр Южный научный центр РАН, просп. Чехова, 41, 344006 г. Ростов-на-Дону, Российская Федерация, boris_raev@mail.ru, https://orcid.org/0000-0001-6006-6173 